\title{
Assessment of serum calcium in relation to dietary calcium intake in a rural population in Cameroon
}

\author{
Niba Rawlings Ngwa, Akwa Emmanuela Ambe \\ HAMANI Foundation Training School of Health, Santa, Cameroon \\ Email:nbngwa@gmail.com
}

Received 19 September 2013; revised 19 October 2013; accepted 26 October 2013

Copyright (C) 2013 Niba Rawlings Ngwa, Akwa Emmanuela Ambe. This is an open access article distributed under the Creative Commons Attribution License, which permits unrestricted use, distribution, and reproduction in any medium, provided the original work is properly cited.

\begin{abstract}
The serum calcium levels of patients were assessed as they attended a district hospital in a rural population for a period of one month. A majority of the patients were between the age group of 38 - 77 years. 55 cases were studied. The ratio of males to females was $3: 8$. The results show an increase in abnormal serum calcium level with age. The abnormality in serum calcium was higher in females than in males. The demonstration of poor nutritional intake and lack of other calcium supplements was a predisposing factor to the abnormal calcium levels. It was concluded that the abnormal levels of calcium were as a result of lack of calcium diet.
\end{abstract}

Keywords: Calcium; Dietary Intake; Ratio; Electrolyte; Osteoporosis

\section{INTRODUCTION}

Calcium is one of the main electrolytes in body fluids. In the body, $99 \%$ of calcium is found in bones for the mineralization of bones [1]. The remaining $1 \%$ is found in body fluids where it is important for neuromuscular excitability, cardiac activity, blood coagulation and membrane permeability $[2,3]$. Calcium circulates in plasma in two forms: calcium bound to albumin and free ionized calcium. Serum calcium ranges from 8.8 to $10.4 \mathrm{mg} / \mathrm{dl}$ (2.2 to $2.6 \mathrm{mM}$ ) in healthy subjects. It comprises free ions (51\%), protein-bound complexes (40\%), and ionic complexes (9\%) [4]. Ionized calcium has a normal value of $4.5-5.5 \mathrm{mg} / \mathrm{dl}(1.1-1.4 \mathrm{mmol} / \mathrm{L})$. This value is usually affected by a number of factors including parathyroid hormone and calcitonin secretion, dietary intake and conditions like osteoporosis. Bone mineral content increases throughout childhood [5], peaks in adolescence [6], remains relatively constant in early/late adulthood
[7], and declines in old age. Dietary intake and absorption are essential to provide sufficient calcium to maintain healthy body stores. Approximately $30 \%$ of dietary calcium ingested in a healthy adult is absorbed by the small intestine. Calcium absorption is a function of active transport that is controlled by $1,25(\mathrm{OH}) 2 \mathrm{D}$, which is particularly important at low calcium intakes, and passive diffusion, which dominates at high calcium intakes. Typically, at normal calcium intake, 1,25(OH)2D-dependent transport accounts for the majority of absorption, whereas as little as $8 \%$ to $23 \%$ of overall calcium absorption is caused by passive diffusion [8]. Because almost all dietary calcium intake is absorbed from the upper intestine, frequent meals or oral supplements promote net calcium absorption. The bioavailability of dietary calcium can be enhanced. Aluminum hydroxide, which binds dietary phosphate [9], when taken in excess leads to hypercalciuria from increased calcium absorption [10].

The people of the rural population under study live on yams as their main source of food. The population of this area is made up of elderly people due to rural-urban migration of the young and middle age adults in search for greener pastures. These people frequent the hospital due to pains in their muscles and bones.

\section{MATERIALS AND METHODS}

\subsection{Sample Size}

A study of 55 cases with age range from 38 - 77 years and belonging to both genders was conducted on "serum calcium in relation to their diet" at a district hospital. The study was carried out from April to May 2013.

\subsection{Data Collection}

Patients who were registered to the laboratory for serum calcium test responded to questionnaires from the researcher. The questionnaires were filled face to face with 
the respondents by the researcher and one assistant. It included information on usual diet intake and physical wellbeing of the respondents.

For the question on usual diet, the responses were categorized into 1) yams only 2) yams with meat or fish, 3) yams, meat or fish and other milk products.

For questions on the physical wellbeing, responses were categorized into 1) physically fine 2) mild body pains 3 ) serious body pains.

\subsection{Statistical Analysis}

Statistical analysis of data generated was done with statistical package for social sciences (SPSS). The data was analyzed using Analysis of Variance (ANOVA). P $<0.05$ is considered significant.

\subsection{Estimation of Serum Calcium}

Venous blood was collected in plain vacutainers and serum was immediately separated by centrifugation. The serum samples were then stored at $4^{\circ} \mathrm{C}$ and analyzed within 24 hours.

\section{RESULTS}

Over a period of one month, 55 cases were analyzed for serum calcium levels. The age group of the cases ranged from 38 - 77 years with a males-to-females ratio of 3:8. There was an increase in abnormality of calcium levels with age shown on Table 1. From the ratio of males to females as shown on Table 2, serum calcium abnormality is higher in females than in males. Osteoporosis was the most common comorbid condition followed by muscle spasm and tetany as seen on Table 3 . From the responses shown on Table 4 the people of this area live sorely on yam produce and rarely on meat, fish and other milk products. Table 5 shows the recommended calcium level for various age groups. From the responses of the people in this area as seen on Table 4, there is no doubt that their calcium is not within the recommended levels since they don't get dietary supplements.

\section{DISCUSSION}

Figure 1 shows that abnormality in serum calcium increases with age. This confirms the fact that elderly peo-

Table 1. Age distribution.

\begin{tabular}{ccc}
\hline Age group (years) & $\mathbf{N}^{\circ}$ of patients & \% total patient \\
\hline $38-47$ & 5 & 9.09 \\
$48-57$ & 9 & 16.36 \\
$58-67$ & 16 & 29.09 \\
$68-77$ & 25 & 45.45 \\
\hline
\end{tabular}

Table 2. Sex distribution.

\begin{tabular}{cccc}
\hline Age group (years) & Males (M) & Females (F) & Ratio (M/F) \\
\hline $38-47$ & 2 & 3 & $1: 1.5$ \\
$48-57$ & 3 & 6 & $1: 2$ \\
$58-67$ & 4 & 12 & $1: 3$ \\
$68-77$ & 6 & 19 & $1: 3.2$ \\
Total & 15 & 40 & $3: 8$ \\
\hline
\end{tabular}

Table 3. Comorbid conditions.

\begin{tabular}{ccc}
\hline Conditions & $\mathbf{N}^{\circ}$ of patients & \% of total patients \\
\hline Osteoporosis & 52 & 94.55 \\
Muscle spasms & 45 & 81.82 \\
Tetany & 21 & 38.18 \\
\hline
\end{tabular}

Table 4. Questionnaire responses.

\begin{tabular}{cccccccc}
\hline \multirow{2}{*}{$\begin{array}{c}\text { Age gp } \\
\text { (yrs) }\end{array}$} & $\begin{array}{c}\text { No of } \\
\text { patients }\end{array}$ & $\begin{array}{c}\text { Response (R) question } \\
\text { on usual diet }\end{array}$ & \multicolumn{4}{c}{$\begin{array}{c}\text { Response (R) question } \\
\text { on physical wellbeing }\end{array}$} \\
\cline { 3 - 8 } & & R1 & R2 & R3 & R1 & R2 & R3 \\
\hline $38-47$ & 5 & 4 & 1 & 0 & 0 & 2 & 3 \\
$48-57$ & 9 & 6 & 3 & 0 & 0 & 4 & 5 \\
$58-67$ & 16 & 12 & 3 & 1 & 0 & 2 & 14 \\
$68-77$ & 25 & 15 & 8 & 2 & 0 & 8 & 17 \\
\hline
\end{tabular}

Table 5. Recommended calcium intake.

\begin{tabular}{cc}
\hline Group & Recommended intake mg/day \\
\hline Infants and children & \\
\hline 0 - 6 months & 300 \\
Human milk & 400 \\
Cow milk & 400 \\
7 - 12 months & 500 \\
1 - 3 years & 600 \\
4 - 6 years & 700 \\
7 - 9 years & $1300^{\mathrm{a}}$ \\
Adolescents, 10 - 18 years & \\
Adults & \\
Females & 1000 \\
19 years to menopause & 1300 \\
Postmenopause & \\
Males & 1000 \\
19 - 65 years & 1300 \\
$65+$ & 1200 \\
Lactation & 1000 \\
\hline
\end{tabular}




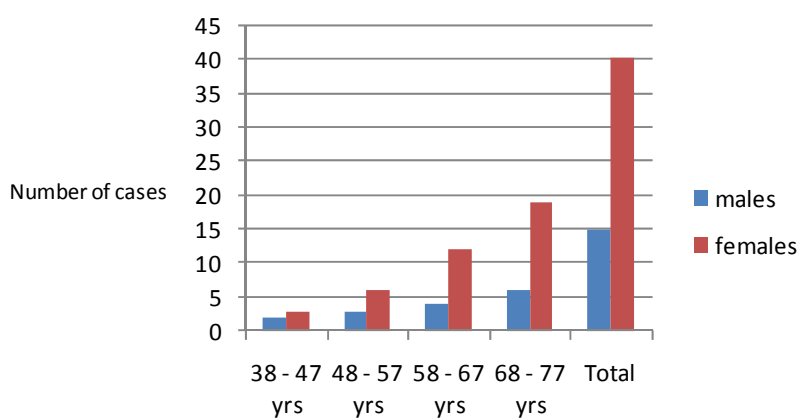

Figure 1. Bar chart showing the distribution of serum calcium by age and sex.

ple experience loss of bone mass (osteoporosis) which intern affects the serum calcium level. Bone mineral content increases throughout childhood [5], peaks in adolescence [6], remains relatively constant in early/late adulthood [7], and declines in old age. Table 2 shows that abnormality in serum calcium is higher in females than in males. In the African traditional context, the man provides the meat or fish to be used for cooking but the woman after cooking has to put all the meat and fish and serve it to the man. This practice is carried out in this rural community and it gives the men a greater chance of increasing their dietary calcium than the women. Dietary reference intakes, developed in 1997, recommend calcium intakes of 1000 to $1500 \mathrm{mg} / \mathrm{d}$ in healthy individuals, depending on age [11]. Calcium supplements with or without vitamin $\mathrm{D}$ have long been used to slow bone loss and the development of osteoporosis in adults [12]. This is particularly common in the elderly, whose diets are frequently insufficient to meet the dietary reference intakes. Calcium supplementation that reverses calcium insufficiency decreases bone loss in older individuals [12, 13]. These values represent the minimum amount of calcium needed to achieve maximal retention based on calcium balance studies in various age groups. It was reasoned that achieving maximal retention should optimize bone mass during peak bone growth in childhood, promote bone consolidation in adulthood, and minimize bone loss in old age. The prevailing beliefs are that any calcium in excess of the maximal retention intake would achieve no increase in retention, offer no additional benefit, and would not be detrimental. Table 3 which shows the associate conditions to abnormal calcium levels are partly as a result of loss of bone mass (osteoporosis) due to increase age and lack or shortage of dietary calcium intake. It has been hypothesized that bone can release to, and remove calcium from, the circulation by active mechanisms separate from the remodeling system [14]. However, although bone acts as a temporary buffer to take up and release serum calcium, the mechanism is largely passive and driven by the serum calcium concentration itself. Symptoms of hypocalcaemia include; Painful muscle spasm and cramps, Twitching of muscles, Numbness or tingling in feet and hands and Numbness or tingling around the mouth. From the responses as shown on Table 4 the people of this area live sorely on yam produce and rarely on meat, fish and other food sources rich in calcium like milk products. Other calcium supplements which are to be included are not due to the economic situation of the people playing a great role to this dilemma. The Vicious triangle of ignorance, poverty and disease is a great problem to the people of this community.

\section{CONCLUSION}

There is a clear cut-out relationship between the dietary calcium intake and the serum calcium level as shown on Tables 4. This is to say that the serum calcium level is greatly dependent on the dietary calcium intake. Since the physiological change, called age is one of the main factors of bone loss. Dietary calcium and other calcium supplement will go a long way to balance the serum calcium levels especially for the elderly people of this community.

\section{REFERENCES}

[1] Wang, L., Nancollas, G.H. and Henneman, Z.J. (2006) Nanosized particles in bone and dissolution insensitivity of bone mineral. Biointerphases, 1, 106-111. http://dx.doi.org/10.1116/1.2354575

[2] Campbell, A.K. (1990) Calcium as an intracellular regulator. Proceedings of the Nutrition Society, 49, 51-56. http://dx.doi.org/10.1079/PNS19900008

[3] Bootman, M.D., Collins, T.J., Peppiatt, C.M., Prothero, L.S., MacKenzie, L., DeSmet, P., Travers, M., Tovey, S.C., Seo, J.T., Berridge, M.J., Ciccolini, F. and Lipp, P. (2001) Calcium signalling-An overview. Seminars in Cell \& Developmental Biology, 12, 3-10. http://dx.doi.org/10.1006/scdb.2000.0211

[4] Robertson, W.G. and Marshall, R.W. (1979) Calcium measurements in serum and plasma-Total and ionized. CRC Critical Reviews in Clinical Laboratory Sciences, 11, 271-304. http://dx.doi.org/10.3109/10408367909105859

[5] Lu, P.W., Briody, J.N., Ogle, G.D., Morley, K., Humphries, I.R., Allen, J., Howman-Giles, R., Sillence, D. and Cowell, C.T. (1994) Bone mineral density of total body, spine, and femoral neck in children and young adults: A cross-sectional and longitudinal study. Journal of Bone and Mineral Research, 9, 1451-1458. http://dx.doi.org/10.1002/jbmr.5650090918

[6] Bailey, D.A., Martin, A.D., McKay, H.A., Whiting, S. and Mirwald, R. (2000) Calcium accretion in girls and boys during puberty: A longitudinal analysis. Journal of Bone and Mineral Research, 15, 2245-2250. http://dx.doi.org/10.1359/jbmr.2000.15.11.2245

[7] Teegarden, D., Proulx, W.R., Martin, B.R., Zhao, J., McCabe, G.P., Lyle, R.M., Peacock, M., Slemenda, C., John- 
ston, C.C. and Weaver, C.M. (1995) Peak bone mass in young women. Journal of Bone and Mineral Research, 10, 711-715.

http://dx.doi.org/10.1002/jbmr.5650100507

[8] McCormick, C.C. (2002) Passive diffusion does not play a major role in the absorption of dietary calcium in normal adults. Journal of Nutrition, 132, 3428-3430.

[9] Bailey, D.A., Martin, A.D., McKay, H.A., Whiting, S. and Mirwald, R. (2000) Calcium accretion in girls and boys during puberty: A longitudinal analysis. Journal of Bone and Mineral Research, 15, 2245-2250. http://dx.doi.org/10.1359/jbmr.2000.15.11.2245

[10] Teegarden, D., Proulx, W.R., Martin, B.R., Zhao, J., McCabe, G.P., Lyle, R.M., Peacock, M., Slemenda, C., Johnston, C.C. and Weaver, C.M. (1995) Peak bone mass in young women. Journal of Bone and Mineral Research, 10, 711-715. http://dx.doi.org/10.1002/jbmr.5650100507

[11] Institute of Medicine Standing Committee on the Scien- tific Evaluation of Dietary Reference Intakes Food and Nutrition Board (1997) Dietary reference intakes for calcium, phosphorus, magnesium, vitamin $\mathrm{D}$, and fluoride. National Academy Press, Washington DC.

[12] Tang, B.M., Eslick, G.D., Nowson, C., Smith, C. and Bensoussan, A. (2007) Use of calcium or calcium in combination with vitamin D supplementation to prevent fractures and bone loss in people aged 50 years and older: A meta-analysis. Lancet, 370, 657-666. http://dx.doi.org/10.1016/S0140-6736(07)61342-7

[13] McCabe, L.D., Martin, B.R., McCabe, G.P., Johnston, C.C., Weaver, C.M. and Peacock, M. (2004) Dairy intakes affect bone density in the elderly. Journal of Bone and Mineral Research, 80, 1066-1074.

[14] Talmage, R.V. and Mobley, H.T. (2008) Calcium homeostasis: Reassessment of the actions of parathyroid hormone. General and Comparative Endocrinology, 156, 1-8. http://dx.doi.org/10.1016/j.ygcen.2007.11.003 